\title{
PEMODELAN DINAMIKA TIPPE TOP (TT) DENGAN KENDALA NON- HOLONOMIK BERBASIS KOMPUTASI FISIKA PADA BIDANG DATAR $\left(\mathbb{R}^{2} \times \operatorname{SO}(3)\right)$
}

\author{
Melly Ariska*, Hamdi Akhsan, Muhammad Muslim \\ ${ }^{I}$ Physics Education, Faculty of Teacher Training and Education, Sriwijaya University \\ Palembang-Prabumulih Street KM 32 Indralaya, Ogan Ilir, South Sumatra 32155, Indonesia \\ *e-mail: mellyariska@ffkip.unsri.ac.id
}

\begin{abstract}
ABSTRAK
Pemodelan sistem dinamik dalam real-time sangat penting dalam kemajuan teknologi otomatis yang berkembang pesat saat ini, seperti metode perencanaan sistem robotic. Artikel ini menjelaskan sistem dinamik benda tegar dengan kendala non-holonomik pada ruang konfigurasi $\mathbb{R}^{2} \times \mathrm{SO}(3)$. Metode yang digunakan adalah Motion Planning Network dan simulasi numerik dengan komputasi fisika yang dapat digunakan untuk sistem benda non-holonomik yang bergerak secara real-time dengan Pendekatan Jellet Invarian (JI). Pendekatan JI dapat menghasilkan persamaan sistem gerak dan mengevaluasi simulasi model benda dengan kendala non holonomik dan juga menampilkan hasil eksperimen dinamika benda tegar dalam ruang konfigurasi $\mathbb{R}^{2} \times \mathrm{SO}(3)$. Sistem gerak benda dengan kendala non holonomik yang digunakanadalah Tippe top (TT). TT adalah mainan yang mirip seperti gasing yang jika diputar dapat membalik sendiri dengan batangnya.Penulis telah menyelesaikan dinamika gerak TT secara realtime dengan syarat awal bervariasi pada ruang konfigurasi $\mathbb{R}^{2} \times \mathrm{SO}(3)$.Dinamika TT dalam ruang konfigurasi $\mathbb{R}^{2} \times \mathrm{SO}(3)$ telah dimodelkan menggunakan grafik dengan cara memprediksi gerak TT dalam syarat awal yang bervariasi untuk berbagai sudut elevasi saat awal diputar dengan komputasi berbasis Maple 18.
\end{abstract}

Kata Kunci: Kendala non holonomik; Dinamika; Ruang Konfigurasi; Tippe Top (TT).

\section{ABSTRACT}

[Title: Modelling Dynamics of Tippe Top (TT) with non-Holonomic Constraints on the Configuration Space $\mathbb{R}^{2} \times \mathrm{SO}(3)$ ] Reliable real-time modelling for dynamic systems is crucial in today's rapidly growing automated ecosystem, such as the environment and methods of planning a robotic system. This paper describes the rigid dynamics system with non-holonomic constraints on the $\mathbb{R}^{2} \times \mathrm{SO}(3)$ configuration space. The method used is the motion planning network and numeric treatment using physics computation which can be used for non-holonomic object systems that move in real-time with Jellets Invarian (JI) approach. The JI approach can result in a motion system equation and evaluate the model of an object with non-holonomic constraints and also display experimental results for navigation in the $\mathbb{R}^{2} \times \mathrm{SO}(3)$. configuration space. The motion system with non-holonomic constraints used is Tippe top (TT). TT is a toy like a top which when rotated will flip itself with its stem. The author succeeded in describing the dynamics of TT motions in real time with the initial conditions that have been determined with various coordinate in the $\mathbb{R}^{2} \times \mathrm{SO}(3)$ configuration space.

Keywords: Non-holonomic constraints; Dynamics; Configuration space; Tippe top (TT).

\section{PENDAHULUAN}

Mekanika geometri adalah studi fisika, matematika dan teknik, yang berisi banyak topik penelitian. Banyak ide dan perkembangan dalam mekanika geometri telah berperan dalam disiplin ilmu lain untuk menangani masalah praktis [1]. Mekanika geometris terapan dapat ditemukan di berbagai bidang seperti robotika, dinamika kendaraan, dan gerak lokomotif pada berbagai gerak hewan yang melibatkan mekanika non-holonomik [2].

Fenomena berputar, tergelincir dan menggelinding, hambatan holonomik pada permukaan datar, dengan gesekan pada titik kontak, telah dipelajari selama lebih dari satu abad, dan memang persamaan yang mengatur perilaku telah dikenal sejak karya Euler. Oleh karena itu, dapat dipikirkan bahwa tidak banyak lagi yang bisa dikatakan tentang masalah yang sangat klasik ini. Namun yang mengejutkan, semua perlakuan yang memperhitungkan slip dan gesekan pada titik kontak yang telah kami lacak [3-7] membuat asumsi bahwa bagian permukaan tubuh yang membuat kontak dengan meja adalah bola. Ini mungkin perkiraan yang baik dengan mempertimbangkan stabilitas putaran terhadap vertikal, atau untuk puncak 
dengan titik tajam yang dapat didekati secara lokal oleh belahan bumi, atau untuk benda hampir bulat yang distribusi kerapatannya sedemikian rupa sehingga pusat -massa dipindahkan sepanjang sumbu simetri dari pusat volumenya, tetapi jelas gagal untuk menggambarkan perilaku benda seperti bola ketika sumbu simetri dicondongkan pada sudut sembarang terhadap vertikal. Dalam situasi seperti itu, asumsi kebulatan jelas tidak dapat diterima. Pendekatan awal untuk masalah ini secara singkat dijelaskan oleh [8-10]. Di bawah pendekatan EularLagrange ini, ditemukan bahwa produk skalar dari momentum sudut dan vektor dari pusat massa $\mathrm{O}$ ke titik kontak P adalah konstanta gerak. Konstanta ini pertama kali diperoleh untuk kasus spherical-tippe top oleh Kilin AA dan Pivovarova EN (2020), BouRabee NM, Marsden JE dan Romero LA (2004), Lewis AD (2017) [11-13]. Ini telah memainkan peran kunci dalam beberapa analisis tippe top yang telah diterbitkan $[3,14]$. Fakta bahwa invarian Jellett masih tetap invarian untuk benda arbitrer axisimetris di bawah pendekatan Eular-Lagrange, dan fakta itulah yang menyebabkan penyederhanaan masalah yang mendalam.

Namun, penelitian mereka tidak menganalisis solusi numerik untuk benda asimetris dengan kendala holonomik. Sistem non-holonomik diperkenalkan dalam mekanika oleh Ariska M, Akhsan H dan Muslim M (2020a), Lewis AD (2017), Ariska M, Akhsan H dan Muslim M (2020b) $[2,13,15]$, yang berarti bahwa sistem mengalami kendala yang membatasi kecepatan partikel sistem dalam ruang konfigurasi [16]. Kendala adalah kondisi yang membatasi gerak suatu sistem mekanis sehingga mengurangi derajat kebebasan [17]. Kendala holonomik selalu melibatkan kecepatan sistem dan dapat ditulis dalam bentuk derajat satu [6]. Kendala tersebut terdapat pada ruang konfigurasi dan tidak mengurangi derajat kebebasan serta membatasi pergerakan sistem dalam ruang konfigurasi dan momentum [15]. Sistem tersebut dapat digambarkan dengan keragaman (manifold), yaitu upaya membangun koordinat suatu ruang dalam bentuk kumpulan titik, garis atau fungsi [18]. Ruang konfigurasi yang digunakan berupa grup Lie, maka untuk mencari kendala teori grup dapat digunakan, namun dalam penelitian ini hanya perlu menggunakan perhitungan diferensial [19-22].

Kendala non-holonomik diatur oleh persamaan dinamis yang bergantung pada turunan waktu dari ruang konfigurasi sistem [12,22,23]. Kendala tersebut muncul di banyak aplikasi, mulai dari navigasi mobile robot hingga needle steering dalam operasi robot [24]. Untuk menggeneralisasi, itu datang dalam kasus di mana ruang kontrol sistem berdimensi lebih rendah daripada ruang konfigurasinya. Misalnya, pada robot seperti mobil, input kontrolnya adalah kecepatan linier dan sudut, sedangkan konfigurasi atau ruang gerak robot adalah tiga dimensi. Akibatnya, lintasan yang layak di ruang konfigurasi robot mungkin tidak layak sehubungan dengan dinamika sistem $[5,25]$. Dalam makalah ini, dinamika yang dianalisis adalah dinamika pergerakan Tippe Top (TT) di ruang konfigurasi $\mathbb{R}^{2} \times \mathrm{SO}(3)$. TT sebagai bola simetris aksial yang menggelinding dan meluncur pada permukaan $\mathbb{R}^{2} \times \mathrm{SO}(3)$ berdasarkan metode reduksi Jellet Invarian (JI) yang merupakan solusi persamaan gerak benda tegar.

Persamaan gerak tidak dapat diintegrasikan dan sulit untuk dianalisis. Sebuah TT adalah contoh sederhana dari sistem gerak lokomotif dengan kendala non holonomik, tetapi studi mekanik tidak sepele dan tidak kompleks [15,16]. TT adalah mainan berbentuk bola terpotong dengan pasak kecil. Ketika mainan diputar pada bagian bulatnya pada permukaan datar atau permukaan bagian dalam tabung, mainan akan mulai terbalik untuk berputar pada pasaknya [7]. Kami akan mendekati pemodelan dari perspektif Jellet Invarian (JI) terkontrol, karena JI adalah salah satu cara untuk mengekspresikan energi sistem dengan kuat [27]. Selain itu, Jellet Invarian adalah sistem dinamis yang dapat digambarkan dengan serangkaian persamaan diferensial. Dalam makalah ini, persamaan gerak TT diturunkan melalui metode JI dengan perhitungan fisika berbasis Maple 18.

Sistem dengan kendala non-holonomic dapat disembunyikan dengan membuat atau memilih salah satu koneksi Levi-Civita [4,28]. Tujuan menyembunyikan kendala adalah untuk menghilangkan pengali Lagrange dalam persamaan gerak. Makalah ini merupakan upaya untuk lebih memahami sistem dengan kendala non-holonomik dari sudut pandang mekanika geometri, yang menganalisis masalah gerak geometris [15,19,29].

Gerak benda yang dibahas dalam penelitian ini adalah gerak TT. Mengingat gerak TT merupakan contoh gerak benda yang dapat bergerak secara translasi dan rotasi [6,30]. Dalam sebuah penelitian penelitian tentang TT telah berhasil memecahkan persamaan dinamika TT terbalik pada bidang datar sambil menggambarkan persamaan gerak menggunakan fisika komputasi [31]. Analisis sistem dinamis yang kompleks dan rumit yang beroperasi pada bidang datar dan bola pada saat yang sama dengan dan tanpa gesekan telah diselesaikan dengan baik oleh Persamaan Poincare.

Dinamika TT di ruang konfigurasi $\mathbb{R}^{2} \times$ SO(3)dengan bantuan komputasi fisika. Penyelesaian persamaan ini tidaklah mudah, karena konfigurasi 
ruang yang akan dilalui oleh TT merupakan bidang lengkung yang memiliki variabel koordinat bola dan koordinat TT yang bergerak menggunakan tiga sistem koordinat, sehingga jumlah koordinat umum adalah yang harus diselesaikan adalah enam koordinat umum, yaitu dua koordinat translasi dan tiga koordinat rotasi $[15,17]$. Selain itu, peneliti juga menganalisis dan memprediksi pergerakan TT dengan gesekan dengan simulasi grafis secara real time.

Masalah yang dipecahkan dalam penelitian ini adalah bagaimana menganalisis gerak TT dalam komputasi dengan menggunakan jaringan perencanaan gerak dengan Metode JI. Penelitian ini menerapkan teknologi dalam menyelesaikan persamaan umum sistem gerak dalam ruang tiga dimensi. Mengingat semakin berkembangnya ilmu pengetahuan dan teknologi dalam dunia pendidikan, maka dinamika benda yang memiliki konfigurasi ruang yang cukup rumit karena terdiri dari gerak translasi dan gerak rotasi sangat rumit jika diselesaikan secara manual. Penelitian ini merupakan solusi bagi dosen dan mahasiswa dalam menyelesaikan dinamika kompleks objek secara menyeluruh dan tepat. Penelitian ini bertujuan untuk menganalisis dinamika sistem mekanik pada TT dengan kendala non-holonomik yang bergerak pada ruang konfigurasi $\mathbb{R}^{2} \times \mathrm{SO}(3)$ menggunakan komputasi fisika.

Persamaan gerak TT dengan menerapkan teori grup dalam bentuk grup rotasi menggunakan persamaan Poincare pada bidang datar telah dirumuskan dengan perhitungan fisika [22,25]. Selain itu, penelitian sebelumnya tentang dinamika sistem mekanik hanya diformulasikan untuk TT yang beroperasi pada bidang datar. Oleh karena itu penulis tertarik untuk melanjutkan penelitian dengan merumuskan dinamika suatu sistem yang memiliki gerakan yang lebih kompleks yaitu TT yang dimainkan pada bidang lengkung berupa permukaan pada bola dengan cepat dan tanpa gesekan. Prediksi detail gerakan akan dianalisis menggunakan komputasi fisika.

\section{METODE}

Penelitian ini merupakan kajian teoritis matematis yang dilakukan dengan meninjau beberapa pustaka tentang sistem mekanik pada kasus TT yang telah dikembangkan sebelumnya dan perhitungan matematis menggunakan komputasi fisika khususnya berbasis Maple. Metode yang digunakan adalah jaringan perencanaan gerak yang dapat digunakan untuk sistem objek non-holonomik yang bergerak secara real-time dengan pendekatan Jellet Invarian (JI) [7]. Penelitian ini disusun dari perlakuan Numerik dan menyajikan hasil dari beberapa perhitungan berdasarkan sistem eksak,

$$
\begin{gathered}
\frac{d}{d t} \frac{\partial R}{\partial v^{\rho}}-\sum_{\mu=2}^{n} \sum_{\lambda=2}^{n} c_{\mu \rho}^{\lambda} v^{\mu} \frac{\partial R}{\partial v^{\lambda}}-\sum_{\mu=2}^{n}{ }^{\lambda}{ }_{\mu \rho} v^{\mu} \beta_{1} \\
-X_{\rho} R=0, \quad \rho \\
=2, \ldots, n
\end{gathered}
$$

Makalah ini menggunakan metode adaptif berdasarkan rumus diferensiasi numerik orde kedua karena Reduksi Routhian [17,29] dan serupa dengan yang dijelaskan oleh Jellet Invarian (JI) [7,11]. Metode ini memiliki dua sifat yang diinginkan: penerapan adaptasi langkah waktu yang mudah dan kelonggaran sistem yang mungkin kaku. Untuk sebagian besar proses, kami menggunakan toleransi kesalahan relatif $10^{-9}[2,15,17,19]$. Perhitungan yang digunakan adalah Maple 18. Dinamika TT diilustrasikan dengan jelas oleh Maple 18. TT bergerak dalam ruang konfigurasi $\mathbb{R}^{2} \times \mathrm{SO}(3)$.

\section{HASIL DAN PEMBAHASAN}

Perhitungan kendala (konstrain) TT diselesaikan dengan metode Jellet Invarian (JI). Kendala adalah kondisi yang membatasi pergerakan sistem mekanis yang mengurangi baik derajat kebebasan maupun jangkauan setiap derajat kebebasan [23]. Skema dinamika TT dapat dilihat pada Gambar 1 di bawah ini,

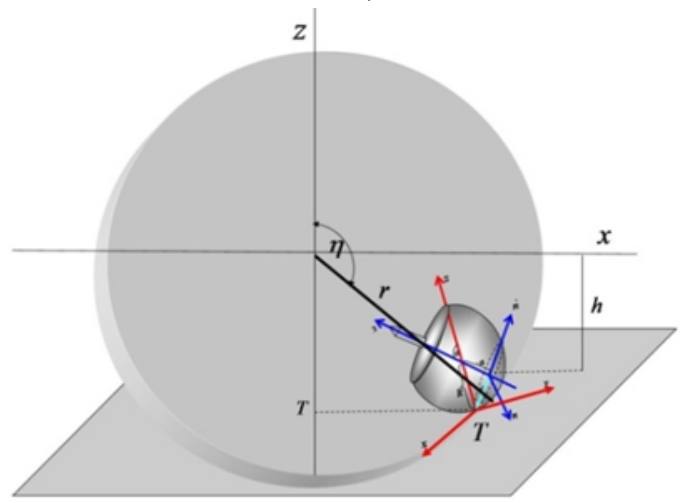

Gambar 1. Skematik dinamika TT

Medan Vektor TT ada ruang konfigurasi $\mathbb{R}^{2} \times \mathrm{SO}(3)$ didapat dengan menggunakan transformasi reduksi Jellet Invarian (JI) Andaikan ada transformasi sebagai berikut,

$$
\mathrm{x}^{\prime}=e^{\mathrm{a} \cdot \mathrm{J}} \mathrm{x}
$$

Pada kasus sistem tanpa gesekan atau non-disipatif, nilai persamaan $\mathbf{J}=-\overrightarrow{\mathbf{L}} \cdot \overrightarrow{\mathbf{r}}$ adalah konstan[13]. Namun, Routh melanjutkan penemuan ini dan membuktikan bahwa itu bukan hanya sistem non-dissipatif. Sistem disipatif juga memiliki konstantaJ $=-\overrightarrow{\mathbf{L}} \cdot \overrightarrow{\mathbf{r}}$ yang konstan. Dengan $\overrightarrow{\mathbf{L}}$ adalah momentum sudut atas terbalik di pusat massa dan $\overrightarrow{\mathbf{r}}$ adalah vektor yang menghubungkan pusat massa dan titik kontak pada permukaan. Di bagian atas sebaliknya, 
ditemukan bahwa invarian Jellet atau konstanta Jellet ditulis sebagai [32]

$$
\begin{array}{r}
\mathbf{J}=-\overrightarrow{\mathbf{L}} \cdot \overrightarrow{\mathbf{r}}(2) \\
=I_{3}(\dot{\psi}+\dot{\phi} \cos \theta)(R \cos \theta-a)+I \dot{\phi} R \sin ^{2} \theta(3)
\end{array}
$$

Sebuah TT bergerak di bidang datar memiliki ruang konfigurasi $\mathbb{R}^{2} \times S O(3)$. Sehingga, TT memiliki dua tipe generator yaitu generator translasi dan generator rotasi. Generator translasi menggambarkan TT bergerak pada ruang konfigurasi $\mathbb{R}^{2}$,

$$
\chi_{x}=\frac{\partial}{\partial x}, \quad \chi_{y}=\frac{\partial}{\partial y}
$$

Sedangkan generator rotasi menggambarkan TT berorientasi pada ruang konfigurasiSO(3)

$$
\begin{aligned}
& R_{\theta}=\frac{\partial}{\partial \theta}=y \frac{\partial}{\partial z}-z \frac{\partial}{\partial y} \\
& R_{\phi}=\frac{\partial}{\partial \phi}=z \frac{\partial}{\partial x}-x \frac{\partial}{\partial z} \\
& R_{\psi}=\frac{\partial}{\partial \psi}=x \frac{\partial}{\partial y}-y \frac{\partial}{\partial x}
\end{aligned}
$$

Persamaan ini dibuat lebih sederhana untuk diselesaikan dengan persamaan Poincaré yang didasarkan pada reduksi Routhian. untuk mencari Lagrangian baru yaitu Routhian, yang diungkapkan sebagai berikut:

$$
R=T-U-\dot{\psi} \frac{\partial T}{\partial \dot{\psi}}
$$

Sehingga, didapatkan Routhian (R) pada TT didapat sebagai berikut, So,

$$
\begin{aligned}
R=\frac{1}{2}\left(I \dot{\theta}^{2}\right. & \left.+I \sin ^{2} \theta \dot{\phi}^{2}+\frac{\left(\beta_{1}\right)^{2}}{I_{3}}\right)-m g(R \\
& -a \cos \theta) \\
& -\left(\frac{\beta_{1}}{I_{3}}-\dot{\phi} \cos \theta\right) \beta_{1}
\end{aligned}
$$

Dinamika TT dirumuskan lebih lanjut menggunakan persamaan Poincaré yang didasarkan pada reduksi Routhian ini. Hasil reduksi Routhian ini $[4,33]$ disubstitusikan persamaan dinamika TT, sehingga didapatkan sebagai berikut $[1,34,35]$

$$
\left[\begin{array}{c}
\ddot{x} \\
\ddot{y} \\
\ddot{\theta} \\
\ddot{\phi} \\
\ddot{\psi}
\end{array}\right]=\left[\begin{array}{c}
-\mu \frac{\left|\mathrm{F}_{N}\right|}{m}(\dot{x}+(R \dot{\psi}+a \dot{\phi}) \sin \theta \cos \phi \\
-\mu \frac{\left|\mathrm{F}_{N}\right|}{m}(\dot{y}+\dot{\theta} \sin \phi(R-a \cos \theta)) \\
\frac{\sin \theta}{I}\left(\cos \theta I \dot{\phi}^{2}+m g a\right)-\frac{\mu\left|F_{N}\right| \dot{x}}{I}(R-a \cos \theta) \\
\left(-\mu\left|F_{N}\right| \dot{y}(a-R \sin \theta)-2 I \dot{\theta} \dot{\phi} \cos \theta\right) \\
\frac{\cos \theta}{I}\left(2 \dot{\phi} \beta_{1}+\mu\left|F_{N}\right| \dot{x}+m g a\right)
\end{array}\right]
$$

Dengan variabel luarnya adalah,

$$
\left|\mathrm{F}_{N}\right|=\frac{m a\left(\cos \theta\left(I \dot{\phi}^{2} \sin ^{2} \theta+I \dot{\theta}^{2}\right)-\beta_{1} \dot{\phi} \sin ^{2} \theta\right)}{I+m a^{2} \sin ^{2} \theta-\mu m a \sin \theta(R-a \cos \theta) \dot{x}}(10)
$$

Solusi numerik dari persamaan gerak terbalik untuk koordinat $\dot{\theta}(t), \dot{\phi}(t), \dot{\psi}(t), \dot{x}(t), \dot{y}(t)$ Dengan kondisi awal TT dituliskan pada Tabel 1. Tabel 1 menjelaskan syarat awal pada TT yang bergerak pada ruang konfigurasi $\mathbb{R}^{2} \times S O(3)$.

Table 1.Syarat awal TT

\begin{tabular}{lccll}
\hline$I_{n}=I_{n}=I$ & $I_{3}$ & $m_{\text {total }}$ & $R$ & $\mathrm{D}$ \\
$\left(\mathrm{gr} . \mathrm{cm}^{2}\right)$ & $\left(\mathrm{gr}_{\mathrm{cm}}\right)$ & $(\mathrm{g})$ & $(\mathrm{cm})$ & $(\mathrm{cm})$ \\
\hline
\end{tabular}

\begin{tabular}{lllll}
\hline 45 & 50 & 13 & 1.3 & 2.6 \\
\hline
\end{tabular}

Nilai kondisi awal Dinamika TT dengan $\theta(0)$ beragam dan heterogen ketika kecepatan untuk setiap koordinat umum adalah $\dot{\theta}(0)=\dot{\phi}(0)=\dot{\psi}(0)=(0)=\dot{x}(0)=$ $\dot{y}(0)=0$ dapat ditunjukkan pada Tabel 2,

Table 2. Kondisi awal dinamika TT saat input Maple 18

\begin{tabular}{ccccc}
\hline No & $\begin{array}{c}\boldsymbol{\theta}(\boldsymbol{t}) \\
\text { rad }\end{array}$ & $\begin{array}{c}\boldsymbol{\beta}_{\mathbf{1}} \\
\mathbf{g m}^{2} \mathbf{r a d} / \mathbf{s}\end{array}$ & $\boldsymbol{\mu}$ & $\begin{array}{c}\text { Waktu TT } \\
\text { membalik (s) }\end{array}$ \\
\hline 1 & 0.1 & 2500 & 0.3 & 23 \\
2 & 0.2 & 2500 & 0.3 & 22 \\
3 & 0.3 & 2500 & 0.3 & 21 \\
4 & 0.4 & 2500 & 0.3 & 21 \\
5 & 0.5 & 2500 & 0.3 & 20 \\
6 & 0.6 & 2500 & 0.3 & 18 \\
7 & 0.7 & 2500 & 0.3 & 18 \\
8 & 0.8 & 2500 & 0.3 & 17 \\
9 & 0.9 & 2500 & 0.3 & Tidak membalik \\
\hline
\end{tabular}

Grafik didapatkan dengan Komputasi fisika dengan Maple 18 berdasarkan syarat dan kondisi awal pada Tabel 1 dan Tabel 2,

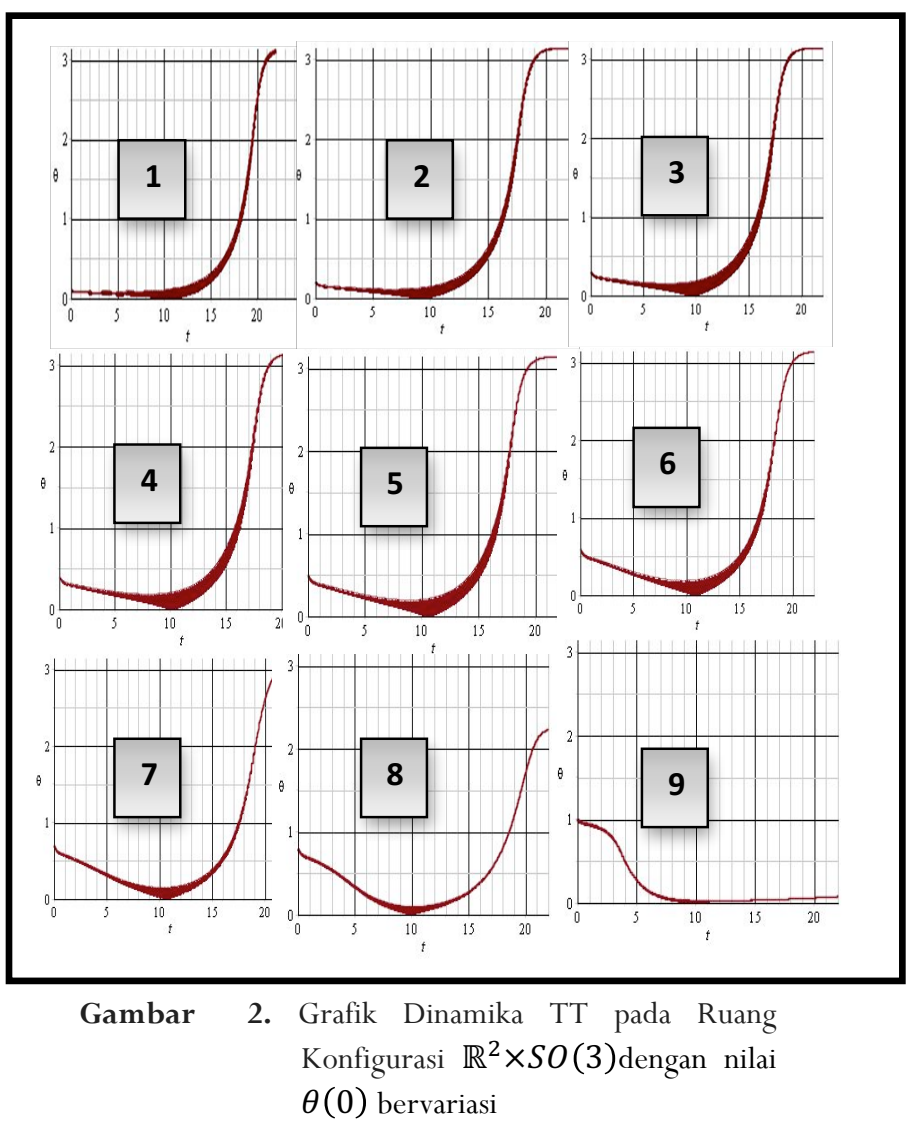

Gambar 2 menunjukkan dinamika TT dengan sudut elevasi $(\theta)$ bervariasi dari $0.1 \mathrm{rad}$ samapai $0.9 \mathrm{rad}$ saat pertama kali dimainkan $(t=0)$. Prediksi dinamikaTT dari awal berputar hingga membalik sampai berputar dengan batangnya dapat dilihat pada Gambar 2 . Pada grafik terlihat bahwa dari awal TT berputar sampai membalik dengan stabil dan presisi tidak lebih dari 23 detik maka TT akan membalik sendiri secara perlahan, 
kemudian setelah $\theta$ membentuk sudut $0.8 \mathrm{rad}$, maka TT akan berputar dengan batang dan berputar dengan mantap dan presisi. Berdasarkan Tabel 2, pada saat TT bergerak pada konfigurasi ruang $\mathbb{R}^{2} \times \mathrm{SO}(3)$, sudut kemiringan $(\theta)$ mula-mula diputar dengan nilai sudut $\theta(0)=0$ sampai tidak lebih dari 0,8 rad, karena pada saat $\theta(0)>0,8 \mathrm{rad}$ maka TT tidak akan membalik dan berputar dengan batangnya.

Analisis keadaan stabil sistem benda tegar diidentifikasi pada Gambar 2. Penulis terus menggunakan model gesekan dalam Reduksi Routh $[15,29]$, yang memungkinkan perlakuan analitis. Analisis ini akan membantu dalam interpretasi lintasan yang dihitung dari sistem yang mengikuti di RauchWojciechowski S, et. Al (2005) [7]. Lintasan ini dapat dihitung baik untuk gesekan atau gesekan Coulomb; seperti yang diakui oleh Ciocci MC (2012), Soodak H (2002) [21,36] untuk kasus spherical-tippe top, ketergantungan pada parameter gesekan mungkin diharapkan berbeda secara kualitatif dalam dua kasus ini.

Penelitian ini mengkaji dinamika benda nonholonomik pada energi rendah dengan maksud bahwa TT hanya dianalisisbergerak di arena berupa $\mathbb{R}^{2} \times \mathrm{SO}(3)$ atau bidang datar yang dianggap cukup besar dari ukuran TT dan penelitiandilakukan tanpa memperhatiksn keadaan non-relativistik klasik.

\section{KESIMPULAN DAN SARAN}

Sistem mekanik dengan kendala nonholonomik dalam ruang konfigurasi $\mathbb{R}^{2} \times \mathrm{SO}$ (3)dapat dijelaskan dengan reduksi Jellet Invarian (JI), yang merupakan sistem dinamika yang dapat dijelaskan oleh satu set persamaan diferensial dan energi sistem seperti yang dinyatakan dengan jelas. Berdasarkan hasil penelitian sebelumnya pada objek sejenis, TT diselesaikan dengan Persamaan Eular-Lagrange, Persamaan Routhian Reduction dan Poincare. Dalam penelitian ini dinamika dinamika TT berhasil diselesaikan dengan Jellet Invarian (JI) yang merupakan turunan dari Routhian dengan bantuan komputasi berbasis Maple pada ruang konfigurasi $\mathbb{R}^{2} \times \mathrm{SO}(3)$.Penulis berhasil menggambarkan dinamika gerak TT secara real time dengan kondisi awal yang telah ditentukan dengan berbagai koordinat. Dinamika TT dalam ruang konfigurasi $\mathbb{R}^{2} \times \mathrm{SO}(3)$ dapat diilustrasikan menggunakan grafik dengan memprediksi gerak TT dengan berbagai sudut elevasi ketika awalnya diputar dengan komputasi.

Artikel ini dapat menambah pengetahuan tentang teori mekanika geometri dan penerapannya dalam menganalisis sistem mekanik untuk perancangan taman bermain TT yang tepat dan memahami gerak kompleks yang ada di alam. Penelitian ini bermanfaat dalam merancang gerak kompleks di bidang robotika dan dapat menjadi referensi untuk memahami kendala non-holonomik dalam teknologi mekanik, khususnya robotika.

\section{UCAPAN TERIMAKASIH}

Terima kasih pada Universitas Sriwijaya yang telah memberikan hibah Sains, Teknologi dan Seni tahun anggaran 2021 No. SP.DIPA023.17.2.677515/2021, Revisi ke 01 tanggal 16 Maret 2021. Sesuai dengan SK Rektor Nomor 0684/UN9/SK.BUK.KP/2021 tanggal 19 Juli 2021.

\section{DAFTAR PUSTAKA}

[1] Holm DD. Geometric Mechanics. 2011. DOI: $10.1142 / \mathrm{p} 802$.

[2] Ariska M, Akhsan H and Muslim M. Dynamic Analysis of Tippe Top on Cylinder's Inner Surface with and Without Friction Based on Routh Reduction, in: J. Phys. Conf. Ser., 2020. DOI:10.1088/17426596/1467/1/012040.

[3] Branicki M, Moffatt HK and Shimomura Y. Dynamics of an Axisymmetric Body Spinning on a Horizontal Surface. III. Geometry of Steady State Structures for Convex Bodies. Proceedings of the Royal Society A: Mathematical, Physical and Engineering Sciences. 2006; 462(2066): 371-390. DOI: $10.1098 / \mathrm{rspa} .2005 .1586$.

[4] Tembely, M.; Vadillo, D.; Soucemarianadin, A.; Dolatabadi, A. Numerical Simulations of Polymer Solution Droplet Impact on Surfaces of Different Wettabilities. Processes 2019, 7, 798, doi:10.3390/pr7110798.

[5] Fokker AD. The Tracks of Tops' Pegs on the Floor. Physica. 1952; 18(8-9): 497-502. DOI:10.1016/S0031-8914(52)80050-3.

[6] Shimomura Y, Branicki $M$ and Moffatt HK. Dynamics of an Axisymmetric Body Spinning on a Horizontal Surface. II. Self-Induced Jumping. Proceedings of the Royal Society A: Mathematical, Physical and Engineering Sciences. 2005; 461(2058): 1753-1774. DOI:10.1098/rspa.2004.1429.

[7] Rauch-Wojciechowski S, Sköldstam M and Glad T. Mathematical Analysis of the Tippe Top. Regular and Chaotic Dynamics. 2005; 10(4): 333-362. DOI:10.1070/RD2005v010n04ABEH000319.

[8] Ueda T, Sasaki K and Watanabe S. Motion of the Tippe Top: Gyroscopic Balance Condition and Stability. SIAM Journal on Applied Dynamical Systems. 2005; 4(4): 1159-1194. DOI: $10.1137 / 040615985$.

[9] Moffatt HK and Tokieda T. Celt Reversals: A Prototype of Chiral Dynamics. Proceedings of the Royal Society of Edinburgh Section A: Mathematics. 2008; 138(2): 361-368. DOI: $10.1017 /$ S0308210506000679.

[10] C. R osmann, F. Hoffmann, and T. Bertram, "Kinodynamic trajectoryoptimization and control for car-like robots,” in2017 IEEE/RSJInternational Conference on Intelligent 
Robots and Systems (IROS).IEEE, 2017, pp. 5681-5686.

[11] Kilin AA and Pivovarova EN. The Influence of the Rolling Resistance Model on Tippe Top Inversion. 2020; (February). Available from: http://arxiv.org/abs/2002.06335.

[12] Bou-Rabee NM, Marsden JE and Romero LA. Tippe Top Inversion as a Dissipation-Induced Instability. SIAM Journal on Applied Dynamical Systems. 2004; 3(3): $352-377$. DOI: $10.1137 / 030601351$.

[13] Lewis AD. The Physical Foundations of Geometric Mechanics. Journal of Geometric Mechanics. 2017; 9(4): 411-437. DOI:10.3934/jgm.2017019.

[14] Glad ST, Petersson D and Rauch-Wojciechowski S. Phase Space of Rolling Solutions of the Tippe Top. Symmetry, Integrability and Geometry: Methods and Applications (SIGMA). 2007; 3. DOI:10.3842/SIGMA.2007.041.

[15] Ariska M, Akhsan H and Muslim M. Potential Energy of Mechanical System Dynamics with Nonholonomic Constraints on the Cylinder Configuration Space, in: J. Phys. Conf. Ser., 2020. DOI:10.1088/17426596/1480/1/012075

[16] A. H. Qureshi, A. Simeonov, M. J. Bency, and M. C. Yip, "Motionplanning networks," in2019 International Conference on Robotics andAutomation (ICRA). IEEE, 2019, pp. 21182124.

[17] Ariska M, Akhsan H and Zulherman Z. Utilization of Maple-Based Physics Computation in Determining the Dynamics of Tippe Top. Jurnal Penelitian Fisika dan Aplikasinya (JPFA). 2018; 8(2): 123. DOI:10.26740/jpfa.v8n2.p123-131.

[18] Sriyanti I, Ariska M, Cahyati N and Jauhari J. Moment of Inertia Analysis of Rigid Bodies Using a Smartphone Magnetometer. Physics Education. 2020; 55(1). DOI:10.1088/1361-6552/ab58ba.

[19] Ariska M, Akhsan H and Muslim M. Utilization of Physics Computation Based on Maple in Determining the Dynamics of Tippe Top, in: J. Phys. Conf. Ser., 2019. DOI:10.1088/1742-6596/1166/1/012009.

[20] Ciocci MC and Langerock B. Dynamics of the Tippe Top via Routhian Reduction. Regular and Chaotic Dynamics. 2007; 12(6): 602-614. DOI: $10.1134 /$ S1560354707060032.

[21] Ciocci MC, Malengier B, Langerock B and Grimonprez B. Towards a Prototype of a Spherical Tippe Top. Journal of Applied Mathematics. 2012; 2012. DOI:10.1155/2012/268537.

[22] Zobova AA. Comments on the Paper by M.C. Ciocci, B. Malengier, B. Langerock, and B. Grimonprez "Towards a Prototype of a Spherical Tippe Top.” Regular and Chaotic Dynamics. 2012; 17(3-4): 367-369. DOI:10.1134/S1560354712030112.

[23] Johnson JJ, et al. Dynamically Constrained Motion Planning Networks for Non-Holonomic Robots. 2020; . Available from: http://arxiv.org/abs/2008.05112.
[24] Zobova AA. Analitical and Numerical Investigation of the Double-Spherical Tippe-Top Dynamics. n.d.; : 1-25.

[25] Analysis G. Global Analysis of Dynamical Systems. Global Analysis of Dynamical Systems. 2001; DOI:10.1887/0750308036.

[26] Soodak H. A Geometric Theory of Rapidly Spinning Tops, Tippe Tops, and Footballs. American Journal of Physics. 2002; 70(8): 815-828. DOI:10.1119/1.1479741.

[27] B. J. Cohen, S. Chitta, and M. Likhachev, "Search-based planningfor manipulation with motion primitives," in Robotics and Automation (ICRA), 2010 IEEE International Conference on. IEEE, 2010, pp. 2902-2908.

[28] Bou-Rabee NM, Marsden JE and Romero LA. Dissipation-Induced Heteroclinic Orbits in Tippe Tops. SIAM Review. 2008; 50(2): 325-344. DOI: $10.1137 / 080716177$.

[29] Gray CG and Nickel BG. Constants of the Motion for Nonslipping Tippe Tops and Other Tops with Round Pegs. American Journal of Physics. 2000; 68(9): 821-828. DOI:10.1119/1.1302299.

[30] Blankenstein G. Symmetries and Locomotion of a 2D Mechanical Network: The Snakeboard. 2003; (July): 1-16.

[31] E. Huang, M. Mukadam, Z. Liu, and B. Boots, "Motion planning withgraph-based trajectories and gaussian process inference," inRoboticsand Automation (ICRA), 2017 IEEE International Conference on, 2017,pp. 5591-5598.

[32] Domercq C, et al. Hall B. 2015; : 7-8.

[33] Raman, K.A.; Jaiman, R.K.; Lee, T.-S.; Low, H.$\mathrm{T}$. Dynamics of simultaneously impinging drops on a dry surface: Role of impact velocity and air inertia. J. Colloid Interface Sci.2017, 486, 265-276, doi:10.1016/j.jcis.2016.09.062.

[34] Montgomery R. Geometric Mechanics. 2006; 209-220. DOI:10.1090/surv/091/15.

[35] A. Faust, K. Oslund, O. Ramirez, A. Francis, L. Tapia, M. Fiser, and J. Davidson, "Prm-rl: Long-range robotic navigation tasks bycombining reinforcement learning and sampling-based planning,” in 2018 IEEE International Conference on Robotics and Automation (ICRA). IEEE, 2018, pp. 5113-5120..

[36] Langerock B, Cantrijn F and Vankerschaver J. Routhian Reduction for Quasi-Invariant Lagrangians. Journal of Mathematical Physics. 2010; 51(2). DOI: 10.1063/1.3277181.

[37] Branicki M and Shimomura Y. Dynamics of an Axisymmetric Body Spinning on a Horizontal Surface. IV. Stability of Steady Spin States and the "rising Egg" Phenomenon for Convex Axisymmetric Bodies. Proceedings of the Royal Society A: Mathematical, Physical and Engineering Sciences. 2006; 462(2075): 3253-3275. DOI:10.1098/rspa.2006.1727. 